\title{
New spatial conditions of regional development
}

\section{Szymon Opania}

\begin{abstract}
The article deals with the use of spatial planning tools serving to improve the quality of space in post-industrial areas along with the possibilities of using modern technologies in the field of renewable energy sources.

The analysis was carried out on the example of the Upper Silesian metropolis which occupies about $8 \%$ of the region's area with its distinct industrial and post-industrial areas. The urban area determines the image of a region associated with pollutants and a degraded environment. This is a challenge for planners.

Special conditions for the acquisition and use of renewable energy sources are available in the direct vicinity of the central part of the region, in the former Upper Silesian Metropolitan Union (since April 2017 - the Upper SilesiaZagłębie Metropolis). This is the basis for the implementation of the idea of sustainable development along with the development of modern technologies, but above all it is the basis for the restructuring and restoration of Silesian space. In addition, the development of renewable energy sources can help crystallize the area's spatial structure, counteract suburbanisation and help protect valuable agricultural and natural areas. Consequently, prospective spatial planning aimed at improving the quality of brownfield space, along with modern technologies and external funds, may guarantee that the region's potential will be fully exploited and its future development - continuous and dynamic, leading to a change of the area's negative image.

The case study concerns the Upper Silesian agglomeration. However, the adopted directions of development, including the prevention of suburbanisation and the use of agricultural production for renewable energy sources, are universal enough to be used in any other case.
\end{abstract}

\section{General characteristics of the province of Upper Silesia}

The province of Silesia is situated in the central-southern part of Poland, in the catchment area of the upper reaches of Poland's three biggest rivers: the Vistula, the Oder and the Warta. The area is characterized by a varied lie of the land including both uplands (KrakówCzęstochowa Jurassic Highland Chain and Silesian Highlands), the Oświęcim-Racibórz Valley, Silesian Lowlands, mountain ranges of the West Beskidy Mountains and the Silesian Foothills.

The region covers an area of 12,331 $\mathrm{km}^{2} .4 .57$ million people live in the province which constitutes $12.4 \%$ of the population of Poland. Among 16 provinces in the country, the province of Silesia is the most urbanized region of Poland. In terms of administrative structure it consists of 167 municipalities, among which 49 are urban, 22 urban-rural ones and as many as 96 rural [Plan Zagospodarowania Przestrzennego Województwa Ślaskiego 2020+ (Land Development Plan for the Province of Silesia 2020+) 2016].

The province of Silesia is the main industrial region of Poland. It is here that we can find such natural resources as: coal, zinc and lead deposits, iron ores, rock salt, methane seams, marlstone, limestone and natural aggregates deposits. This region plays a crucial role in the national economy as the basis of national fuel-energy resources. 
The province of Silesia is a particular region, one of the most problematic areas in the country. It accounts for a significant part of the national industrial potential with 38 active coal mines, 25 mills and mill facilities, 21 industrial power and heat and power plants as well as 22 commercial power and heat power plants. The dominant sectors of the economy are coal mining and, in second place, metallurgy. Modern, prospective branches like electronics, the automotive industry and food processing are developing faster and faster due to changes resulting from a restructuring of the region's economy.

The main industrial centre is the Upper Silesian Metropolitan Union (GórnośląskoZagłębiowska Metropolia) which consists of 14 cities (including Katowice, the regional capital) and takes up an area of about $1200 \mathrm{~km}^{2}$.

\section{Pic. 1. Location of the Upper Silesian metropolis with Katowice in the administrative system of Poland}

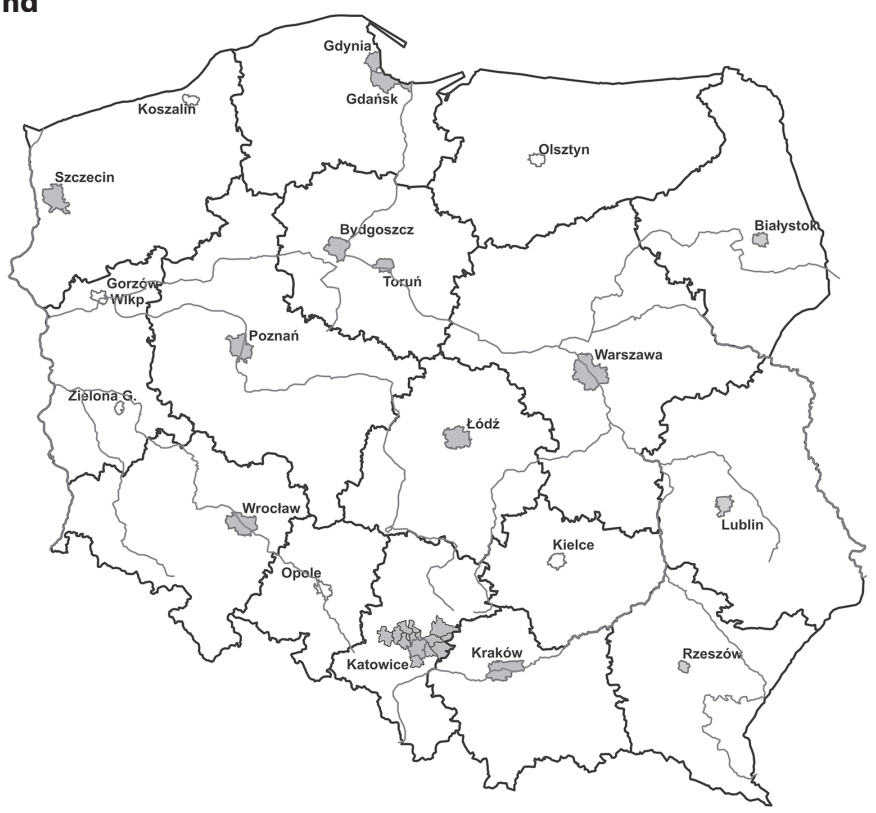

Source: author's own work

The region is associated primarily with highly industrialized areas, but there are also agricultural and touristic areas, both in the northern and southern part of the province.

Despite intensive, centuries-long economic activity carried out on the territory of the Silesia province, forests with well-preserved plant complexes and a variety of flora take up almost $32 \%$ of the area of the region. This includes nature reserves and landscape parks (as much as $4.3 \%$ of the total forest area in Poland). Protected areas take up 270,276.1 ha which constitutes $22 \%$ of the province territory. They are located in two complexes in the north and in the south of the region and consist of 8 landscape parks, 59 nature reserves, 5 naturelandscape complexes and one protected landscape area. 
Unfortunately, the province of Silesia takes first place in the country when it comes to dust pollution emissions as well as gas pollution. Another important factor of air quality in Silesia is the large amount of low-stack emissions of air pollution (generated by transport, local boiler houses and individual coal-based home burners with low heating parameters). Lowstack emission from coal burning also has a big influence on the environment of countryside areas as well as a number of housing estates in small towns.

The condition of the natural environment is to a large extent varied within the province itself (except for degraded and devastated areas there are also recreation areas and places of natural lushness). Among the biggest ecological problems are surface water pollution, the amount of municipal sewage and industrial waste produced, and dust and gas emissions.

The region encompasses one of the most attractive areas of southern Poland when it comes to places of natural interest: the Kraków-Częstochowa Jurassic Highland Chain, the Silesian Foothills and the West Beskidy Mountains. The region is characterized by diversity and a huge, not yet exploited, cultural, landscape and natural potential. The beauty, exceptionality and uniqueness of touristic areas are mainly a result of its varied geological formations. However, tourist attractiveness is decreased by significant environmental degradation. Tourism has become a new profitable economic activity in the province. The potential of the region makes it suitable for development of transit tourism and industrial tourism which is becoming more and more popular.

The countryside areas of the province also have tourist potential and enjoy increasing popularity among tourists visiting the province. Nevertheless, the tourism possibilities of the province are not fully exploited. Excellent conditions are provided by the natural aspects of traditional tourist regions such as the Beskidy Mountains (a mountain range in the southern part of the province with numerous border crossings) and the Kraków-Częstochowa Jurassic Highland Chain (a nature reserve, unique in Europe, from the Jurassic period). The attractiveness of this area is increased by ruins of castles and Piast-dynasty watchtowers ("eagles' nests", including the castle in Ogrodzieniec) and beautifully situated palace-garden complexes with the biggest one in Pilica [Plan Zagospodarowania Przestrzennego Województwa Ślaskiego (Land Development Plan for the Province of Silesia) 2007].

On the basis of data and analysis [Bujakowski 2005] it can be stated that the renewable energy potential in the province is average (when it comes to Poland), taking into consideration modern, possible to implement, technologies. The only exception is biomass which can be considered to have a strong development potential in the province.

The northern part of the region is characterized by a strong (by regional standards) wind energy potential, assuming wind power plants installed at $40 \mathrm{~m}$ above the ground are used. There is also the possibility of developing hydraulic engineering features in this area. In the surroundings of Częstochowa there is also prospectively the largest geothermal energy potential as well as significant potential of biogas from agricultural anaerobic digestion. Municipalities in the northern part of the province also have a large or average biomass potential. 


\section{NEW SPATIAL CONDITIONINGS OF REGIONAL DEVELOPMENT \\ Szymon Opania}

The north-western part of the region is characterized by a large biomass and agricultural biogas potential. The biogas can also be acquired from municipal waste and sewage treatment plants. There are also coal mines with the possible but not significant potential of using mine waters. In this area there might be some local areas with favourable, on the scale of the province, wind energy resources.

The north-eastern part of the province has a large biomass potential, an average agricultural biogas potential and, prospectively, significant possibilities of exploiting geothermal energy. In this area there are coal mines with a significant potential of using mine waters.

The south-western part of the province has an average biomass potential. In this area there are coal mines with a significant potential of using mine waters. The area is characterized by a large agricultural and municipal waste biogas potential and there is the technical possibility of using biogas from a sewage treatment plant. In this part of the region there is a higher than average wind energy potential. In all the districts, geothermal energy can also be used.

In the south-eastern part of the province there are coal mines with a large potential of using mine waters. This area is also characterized by a large agricultural biogas potential and the possibility of using water energy.

The southern part of the province has an average biomass potential. This area is also characterized by an average to large agricultural gas potential. This part of Silesia has the most favourable wind energy resources, in the scale of the province, at all altitudes taken into consideration.

The whole province is characterized by favourable conditions for solar water heating.

The use of renewable energy should increase along with technological development. The profitability of the system should increase along with the increasing efficiency of devices and

\section{Pic. 2. List of possible renewable energy sources in the province of Silesia (\%)}

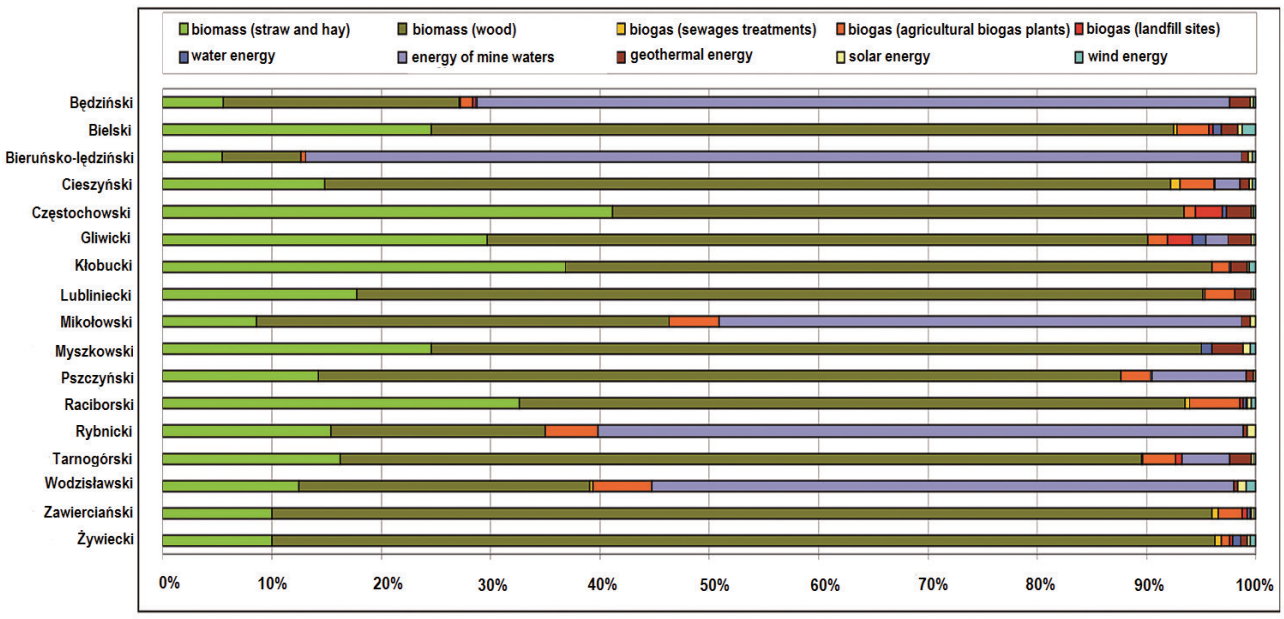

Source: Kubicka A. Opania Sz. 2009. 


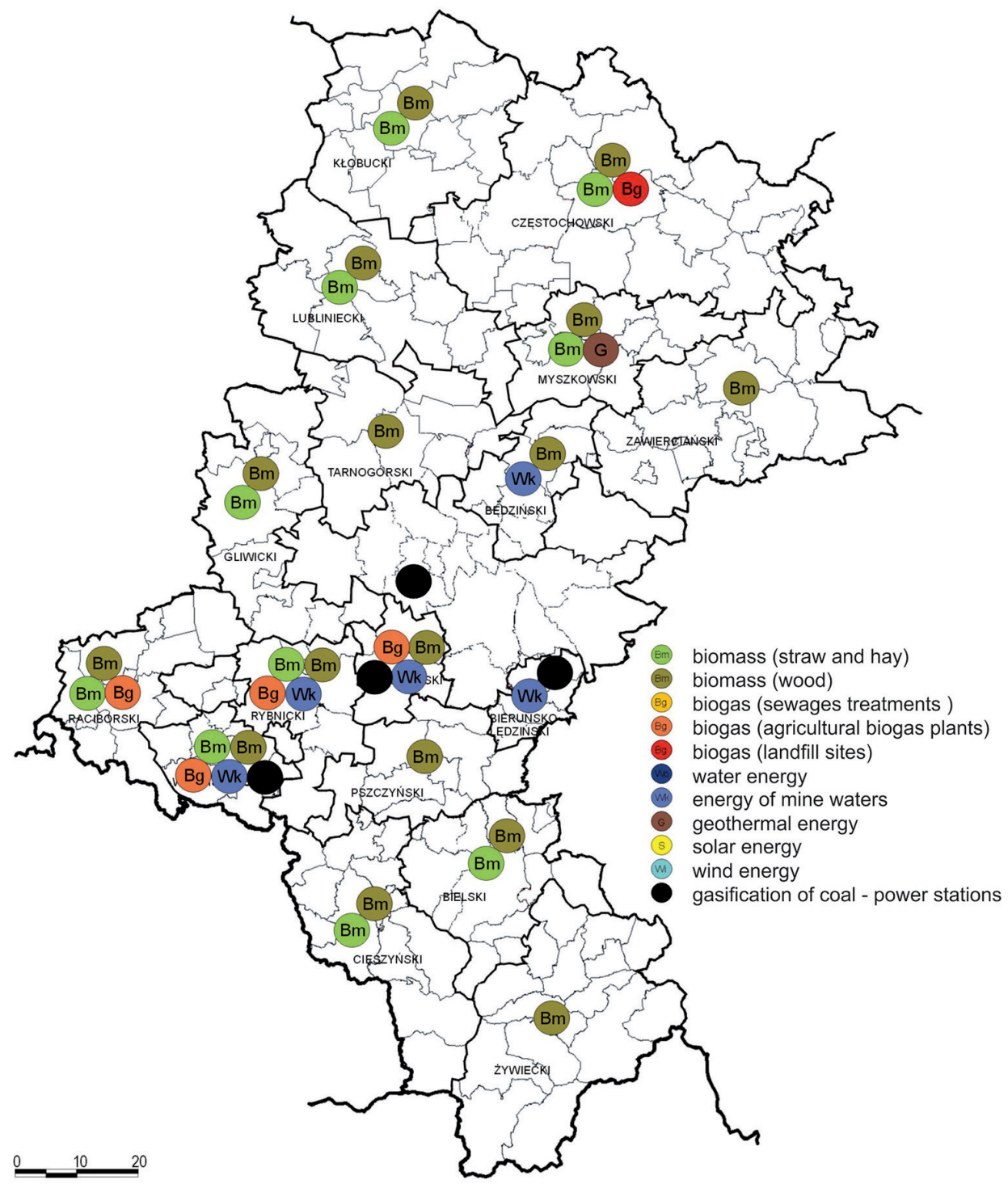

Source: Kubicka A., Opania Sz. 2009

their falling prices due to growing production possibilities. Poland's international obligations should increase the chances for renewable energy sources' competitiveness relative to the mineral resources-based power industry [Bujakowski 2005]. 


\section{The Silesian metropolis - an industrial region}

The central part of the province of Silesia is situated on the Silesian Highlands. The most industrialized and rich in natural resources part of the region, the Upper Silesian Metropolis, currently consists of 14 municipalities associated in the Upper Silesian Metropolitan. It encompasses about $1200 \mathrm{~km} 2$ populated by over 2.5 million inhabitants. The population density of 1642 people per $\mathrm{km} 2$ is several times' higher than the national (122 people $/ \mathrm{km} 2$ ) and European (116 people/km2) average [Plan Zagospodarowania Przestrzennego Województwa Ślaskiego 2020+ (Land Development Plan for the Province of Silesia 2020+) 2016].

The area is characterized by a mix of residential, industrial and post-industrial areas, waste and waste dump areas as well as green areas and wastelands. About $25 \%$ of the urbanized area is actively industrial or post-industrial. Areas degraded by industry constitute $9 \%$ of the area of the metropolis. Presently, in the era of thorough restructuring, it is undergoing a difficult transformation of spatial landscape [Opania 2006].

However, it is worth emphasising that the landscape, at least from the author's point of view, is an external visual reflection of all the phenomena taking place in the area. The positive or negative reception of the landscape reflects the effectiveness of spatial management actions.

The problem of the possibility of restructuring cultural landscape of the Upper Silesian agglomeration lies in its definition, valorisation and ways of using it [Opania 2007].

\section{Pic. 4. Spatial structure of the Upper Silesian metropolis}

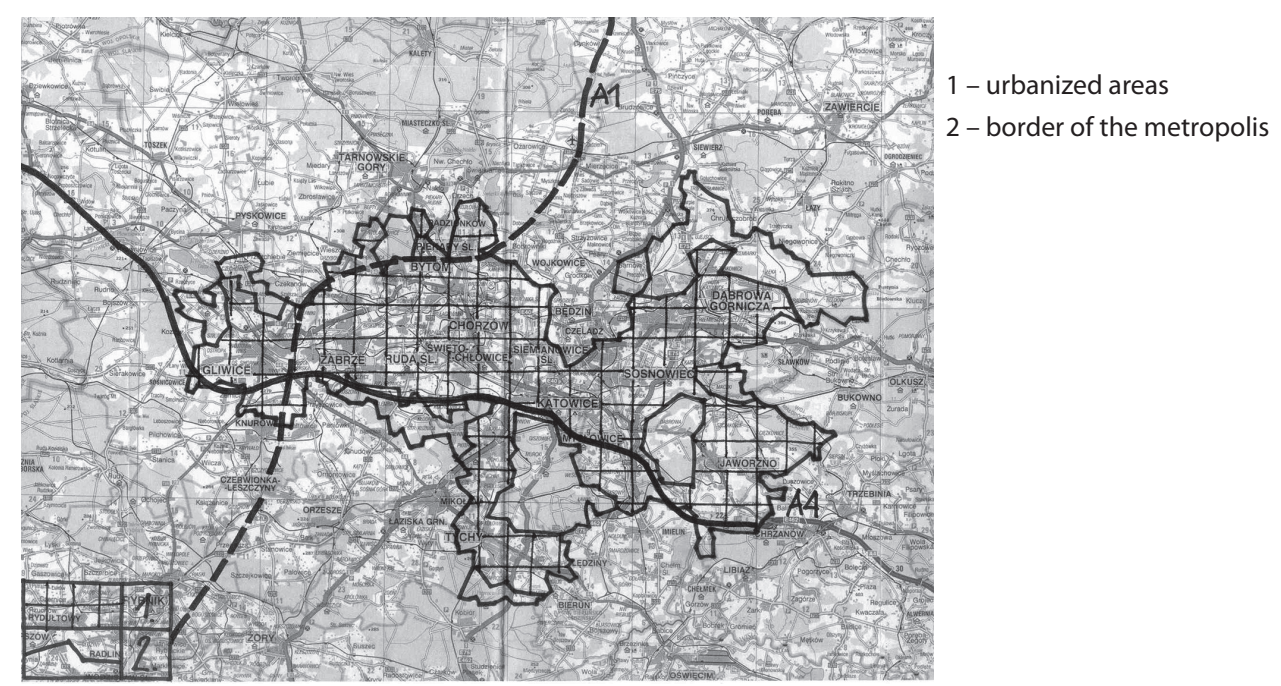

Source: author's own work

In a way, the highly urbanized character of the industrial part of Silesia reflects the character of Europe. For it seems that Europe is defined by its urban character. Almost $80 \%$ 
of the citizens of the EU are inhabitants of urbanized areas. In Poland only about $62 \%$ of population in the cities. However, in the very Upper Silesian metropolis $55 \%$ of the population in cities.

Spatial planning and regional policy in Poland face several challenges in industrial and post-industrial areas. Undoubtedly, narrowing the gap between the infrastructure of Poland and the European Union average is one of the most important and broadly accepted tasks. The process of European integration requires primarily making the most of development chances connected with globalization while at the same time avoiding threats and area conflicts. The Upper Silesian metropolis has been constantly developing due to beneficial politicaleconomic changes which have been taking place since 1989, the favourable location of the region, numerous work places and a low unemployment rate, as well as global tendencies.

Regional policy, carried out at the provincial level, should lead to sustaining the attractiveness of selected regions which may be globally competitive. At the same time, regional development should guarantee maintaining balanced development through resolving the conflict of interest between economic development, environment protection and social cohesion.

\section{Pic. 5. Spatial structure of the Upper Silesian metropolis - desired functions}

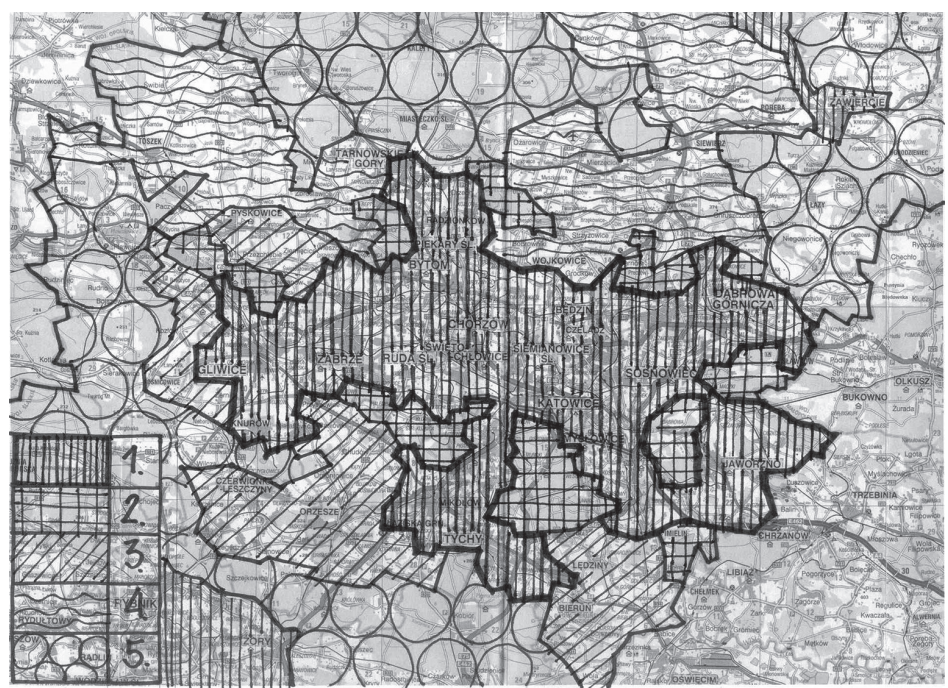

1 - urbanized areas,

2 - areas of recreation function restoration

3 - peripheral areas agricultural-residential 4 - agricultural areas

5 - forest areas

Source: author's own work 


\section{Regional criteria of development and the use of renewable energy sources}

Spatial predispositions towards the development of particular renewable energy sources (RES) in Poland can be determined according to natural factors conditioning their potential, currently available technologies of generating renewable energy and economic calculation. Such an analysis indicates that green electric energy will be produced in Poland in 2020 from wind and water energy as well as from waste biomass, but most of all it will be energy produced in associated sources, heated with biomethane generated from energy plants. It can be assumed that the target structure is the following: electric energy, apart from energy from "energetic" plantations (wind, water, waste biomass) - 10 TWh, i.e. about 22\%, whereas electric energy from "energetic" plantations - 35 TWh, i.e. about 78\%. Taking into consideration the share of various kinds of energy along with the fact that generating wind energy and "energetic" plantations require space, we can notice the significance of this kind of RES in spatial management, and in particular of the necessity to reserve suitable areas [Popczyk, Kocot, Korab, Schmiegel, Kucharczyk, Przekwas 2007].

In the Polish spatial planning system, provinces' strategies and spatial development plans are important documents. One of their significant parts are the recommended development conditions. Very often they are presented in the form of a SWOT analysis in which the chances of increasing the pace of economic development are set against the geographic location and characteristic features of the geographic environment.

When it comes to the province of Silesia, and especially its industrial part connected with mining tradition, the uniqueness of the region results from a strong feeling of regional identity and year-long traditions of good thriftiness as well as the cultural and ethnical diversity of inhabitants. It creates favourable conditions for benefiting from European experience and furthers the mobility of the workforce, not only on a regional, but also European scale. Openness to international contacts, stronger than in other regions of Poland, has resulted in the highest indexes of innovativeness of medium and big enterprises in the country as well as the biggest technical work equipment in Poland. These features are complemented by the development of higher education with its main centres in Gliwice and Katowice.

An important element of the region's competitiveness is the dense rail and road infrastructure network and its location on the axis of a Pan-European corridor, with one existing motorway and another being designed. This results in a level of accessibility within the region unique on a national or even European scale [Węcławowicz 2007]. Due to the spatial conditions of the central, industrial parts of Silesia, the basic factors which influence the possibility of generating and using renewable energy are becoming increasingly apparent. 


\subsection{The suburbanization limitation criterion}

Such an intensively urbanized region shows a tendency towards peripheral development and migration outside central cities. This is one of the causes of the progressing suburbanization of the region along with the "emptying" of the core.

Urbanized areas - strongly and visibly distinguished from the surrounding landscape have predispositions towards the development of services, the housing industry, small and medium enterprises as well as towards shaping urban settlement structures. Such structures often appear in rural municipalities with disappearing agricultural functions. Often they neighbour the already traditional - natural - forms of the landscape [Opania 2006]. This phenomenon has been noticed by planners and urban planners. Therefore guidelines are appearing which indicate the desired dominating functions and their potential locations.

\subsection{Protection of places of natural interest criterion}

The quality of unindustrialized areas is highly valued, as shown by numerous forms of nature and environment protection. Precious natural systems as well as particularly valuable landscape formations in Poland are subject to protection thanks to the national system of protected areas as well as by numerous international programmes aiming at combining protection and economic purposes as well as preserving cultural heritage connected with particular natural formations. To some of these areas, the nearby exploitation of particular renewable energy sources may pose a threat of significant negative environmental effects. These areas include:

- large-format forms of nature protection, including: national parks, nature reserves, landscape parks as well as areas of protected landscape;

- areas included in the Natura 2000 network;

- ECONET-PL ecological network;

- MaB Biospehere reserves (World Network of Biosphere Reserves - Man and the Biosphere Programme by UNESCO);

- RAMSAR list of wetlands (the Convention on Wetlands of International Importance, especially as Waterfowl Habitat).

Spatial activities in areas of nature protection should aim at limiting unfavourable effects of energy generation from RES on places or species of natural interest. Therefore, the following guidelines may be suggested:

- Protected areas (national parks with buffer zones, nature reserves) should be excluded from the possibility of generating energy from water, wind, sun, geothermal sources and biomass.

- In landscape parks (along with possible buffer zones), as well as in areas of protected landscape where arable land and woodlands within their limits are left in their farming character, it is possible to get forest and agricultural products for energetic purposes as 
Pic. 6. Forms of nature protection in parts of the province of Silesia, including its central part

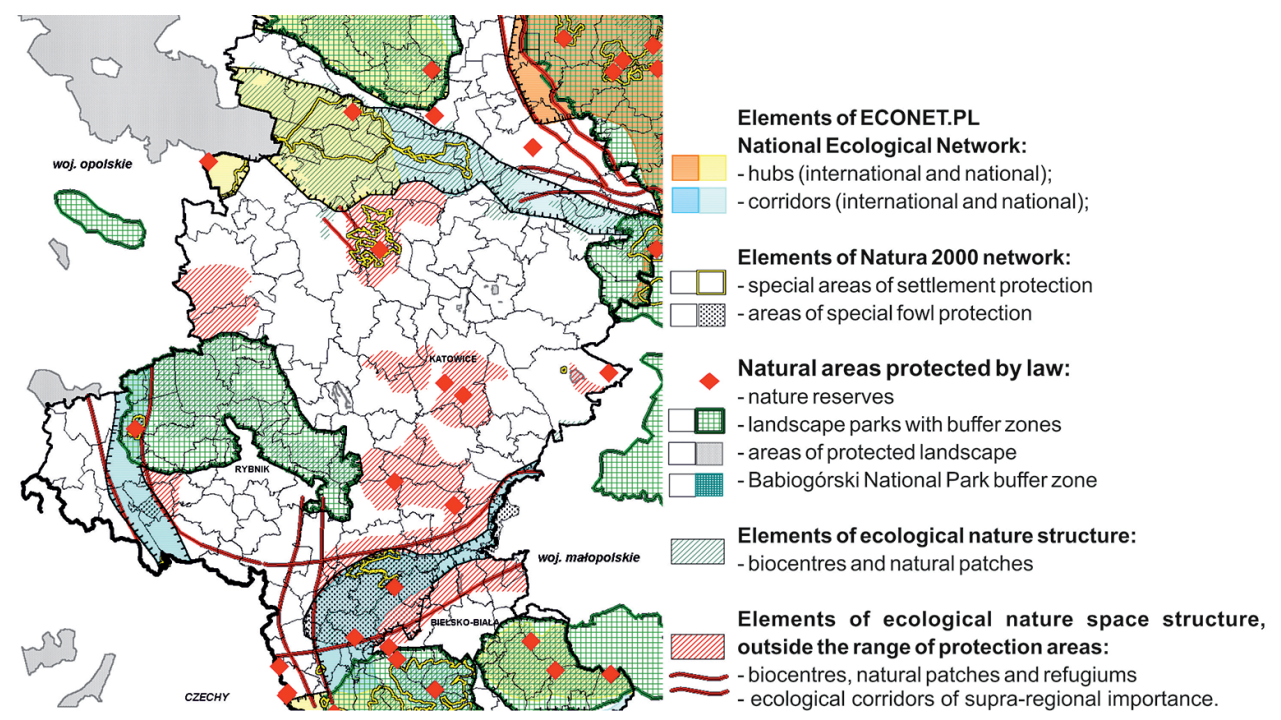

Source: Plan Zagospodarowania Przestrzennego Województwa Śląskiego (Land Development Plan

for the Province of Silesia) 2007

well as solar, geothermal and wind energy on the local scale which shall not threaten the protection of flora and fauna, quality of the landscape or people's recreational-leisure needs.

- Nature 2000 areas should be excluded from the possibility of generating RES on the regional scale. In these areas, both existing ones and ones currently planned, the possibility to invest is limited. Investment is only allowed in case of a lack of alternative solutions when public interest weighs in favour and under the condition of providing ecological compensation.

- Biomass can be acquired both within the limits of Nature 2000 areas, where business, agricultural, forest, hunting or fishing activity is permitted, if it does not infringe on binding regulations concerning these areas, as well as in areas included in the national ecological network ECONET.PL (depending on the individual conditions of particular ecological hubs or corridors). What needs to be taken into consideration is the necessity to preserve, in some cases, the present structure and traditional development methods as well as landscapes of natural interest (the mosaic of natural and anthropogenic ecosystems) and cultural ones. This excludes using a significant area of agricultural lands for energetic purposes, favouring landscape homogeneity or acquiring wood scraps on a large scale. 
Pic. 7. Potential areas of generating energy from renewable sources

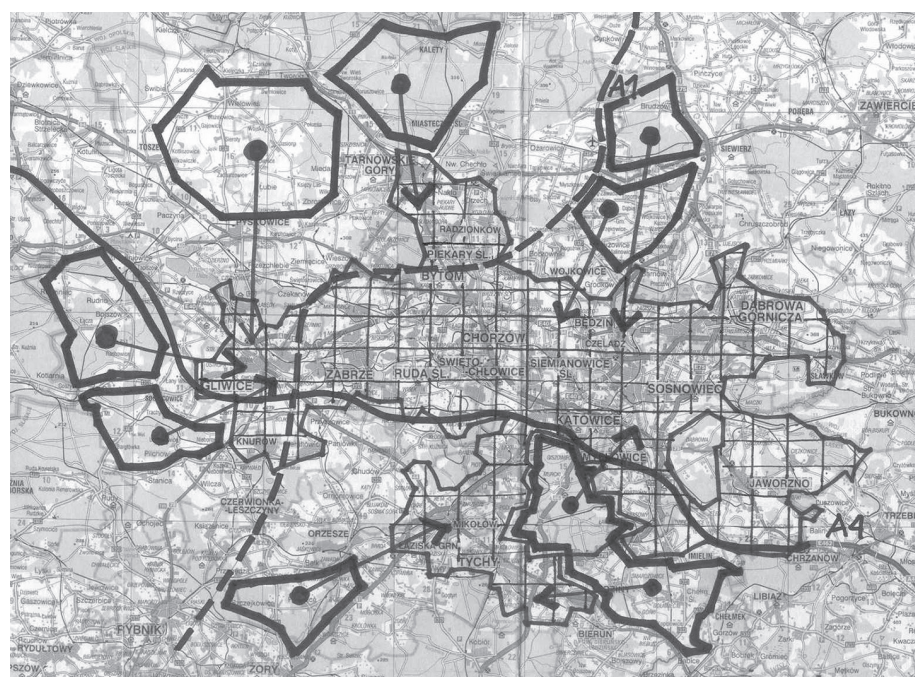

Source: author's own work

Areas of special value to the environment in the province of Silesia are both located peripherally in relation to the metropolis and have potential when it comes to production of renewable energy from biomass. This creates local spatial conflicts when it comes to establishing the dominating function.

\subsection{Protection of agricultural areas criterion}

Assuming the necessity to provide food for metropolitan areas, protection of arable lands is necessary. Taking into consideration the perspective of development, another necessity is the development of ecological agriculture based on traditional methods of land cultivation.

Therefore, the protection of agricultural and woodlands should be based on:

- limiting allocation of agricultural and woodlands for other purposes,

- preventing processes of their degradation and devastation as well as damages in agricultural or forest production and in tree stands resulting from non-agricultural or non-forest activities,

- preventing processes of degradation and devastation of agricultural lands and damage to agricultural production resulting from non-agricultural activity and mass land movements,

- reclaiming and adapting lands for agricultural purposes,

- preserving peat bogs and small ponds as natural water reservoirs,

- restoring and improving the usable value of lands which have lost the character of woodlands as a result of non-forest activity, as well as preventing the lowering of productivity of woodlands. 
Criteria for marking off lands useful for ecological agriculture were based on the analysis of natural soil conditions and the methodological assumptions described for Poland [Ochrona Środowiska - informacje i opracowanie statystyczne (Environment Protection - Information and Statistical Study) 2006]. In the analysis, the method of "multiple scales" enables attributing various strengths to certain factors significant for ecological agriculture by giving them appropriate coefficients. The values of particular indexes are calculated at the municipal level of spatial planning in Poland.

Value of the scales (coefficients) [Ochrona Środowiska - informacje i opracowanie statystyczne (Environment Protection - Information and Statistical Study) 2006] is established according to the expected influence of a given factor on ecological production development. The coefficients for individual factors are presented below:

\begin{tabular}{rcc} 
Index & Symbol & Scales \\
\hline Quality of agricultural production environment & QAPEI & +1.5 \\
Permanent green lands & PGLI & +1.5 \\
Protected lands & PLI & +1.0 \\
Marginal soils & MSI & -1.5 \\
Soil acidity & SAI & -0.5 \\
Soil humusness & SHI & +1.5 \\
Soil pollution with heavy metals & SPWHMI & -1.5
\end{tabular}

For example: Quality of agricultural production environment index QAPEI = WIUNG $x$ P, where: WIUNG - value of valorisation of agricultural production environment index, P - value of scale: 1.5.

Green lands index: GLI = PGL x P, where: PGL $-\%$ of total area taken up by permanent green lands, P - value of scale: 1.5

\section{Pic. 8. QAPEI - quality of agricultural production} environment index in the province

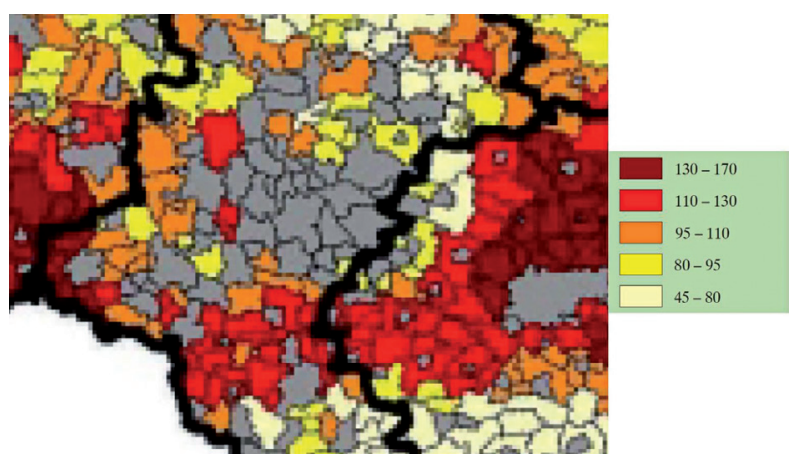

Source: author 's own work, on the basis of: Ochrona Środowiska - informacje i opracowanie statystyczne (Environment Protection Information and Statistical Study)
It was assumed that in municipalities with a higher share of meadowlands and grazing lands there are better conditions for ecological agriculture development, because they enable preserving the organic character of the farm by maintaining the balance between agriculture and animal husbandry. 
Pic. 9. GLI - green lands index in the province

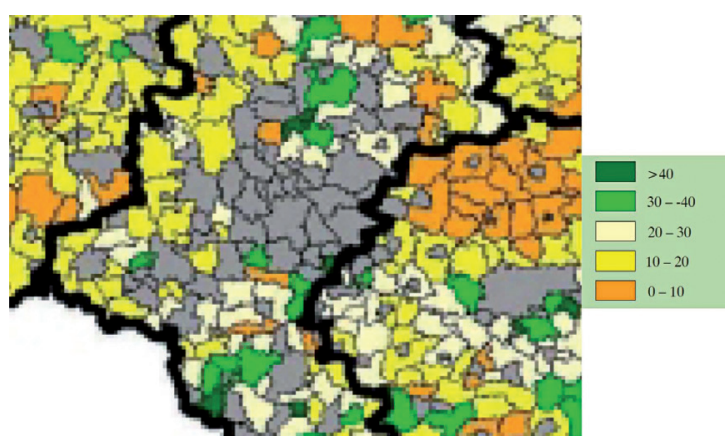

Source: author's own work, on the basis of: Ochrona Środowiska - informacje $i$ opracowanie statystyczne (Environment Protection - Information and Statistical Study)

\section{Pic.10. PLI - protected lands index in the province}

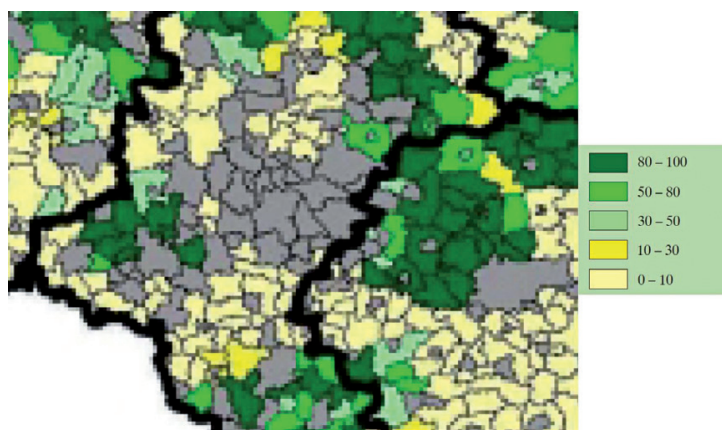

Source: author's own work on the basis of: Ochrona Środowiska informacje i opracowanie statystyczne (Environment Protection - Information and Statistical Study)
Protected lands index: PLI $=$ PROT $x$ P, where - PROT - \% of the total area taken up by lands protected by law, P - value of scales: 1.0.

Arable lands situated on the territory of protected lands or in their direct vicinity are especially useful for ecological agriculture, due to the relative lack of environment pollution as well as the big biological diversity. Protected lands, in accordance with the binding legal regulations, include: national parks and their buffer zones, nature reserves, landscape parks and their buffer zones, areas of protected landscape.

\subsection{International obligations criterion}

The growing demand for electric energy and Poland's signing of international and European conventions entail the necessity to look for new, renewable energy sources. The proper use of the region's potential and its development in the future can be guaranteed by this necessity, resulting in part from signed obligations, along with constant care for post-industrial areas' environment quality and the availability of modern technologies and external funds.

\section{Influence of renewable energy sources on the space of silesia}

Renewable energy sources are spatially dispersed (except for water energy), therefore generation of energy depends on the spatial factor (next to the technological and economic factors). As has been shown, all metropolitan areas can develop primarily biomethane power industry based on appropriately organized power industry agriculture. Only this kind of RES is characterized by appropriate stability and potential. Among the RES discussed above, especially biomethane as well as wind power can influence the shaping of regional and local natural systems. Moreover, the most important benefits of using renewable energy 
sources include the economic development of the region, activation of local communities, possibility to cultivate fallow lands and post-industrial fallow fields and the introduction of an additional source of income for farmers, for example through cultivation of "energetic" plants, increasing industrial cultivations, creating specialized entities dealing with biomass collection or delivery.

The development of a renewable power industry based on biomass in the future means the following for the Upper Silesian metropolis with deep industrial roots - [Gasidło, Popczyk, Kossak-Jagodzińska, Kucharczyk, Mazur, Opania, Pancewicz, Schmiegel 2007]:

- Counteracting suburbanization of peripheral areas of the metropolis, in order to ensure a proper area for agricultural power industry development. Using agricultural lands for energetic cultivations requires large areas, therefore providing terrain reserves in existing rural areas in metropolitan areas or around big cities is required.

- Activities to increase the forestation index of the country. Forestation of wastelands and soils of lower classes (5 and 6) will enable increasing the area of forests as well as acquiring industrial wood and wood scraps for power industry purposes.

- Preventing unfavourable landscape changes is connected with limiting excessive expansion of buildings into non-residential areas, but also the over-dispersion of wind power plants. It is important to aim at locating wind farms in centres around transmission network nodes so as to avoid their over-dispersion, as well as protecting Natura 2000 and ECONET.PL areas.

- Limiting pollution emissions, especially carbon dioxide - a special priority for the province of Silesia. Implementing undertakings based on using ecological fuels may bring about clear-cut environment protection benefits. Changing fuels in big boiler houses or getting rid of individual coal-based energy sources causing "low emission" will decrease the arduousness of the inhabitants' life.

- Increase of the region's energy safety - renewable energy sources result in increasing energy safety on the local and regional scale, improving energy supply, especially for regions with a weak power industry infrastructure.

- Creating additional work places on the local level. Renewable energy sources provide several times more jobs than the traditional power industry due to employment in production and service of machines, production and preparation of biofuels, servicing enterprises. For example, the number of new work places is estimated at 20-26 people per 1000 tons of biofuels produced annually.

- Decreasing the costs of energy generation - the cost PLN/energy unit of biomass (wood, straw) is lower than coal, gas or fuel oil. Moreover, it supports small settlement units with the possibility of alternative, multi-source energy generation.

Other RES are of smaller importance to the spatial structure. Their influence on natural systems can take place through:

- Promoting the region as ecologically clean - an important issue, especially in the region of Silesia with an established image of an industrial area, and in the parts of Silesia where development of recreational-leisure functions is predicted. 
- In areas of the country which are especially important for environment protection (i.e. landscape parks), introducing an obligatory share of solar energy in the balance of satisfying energy needs of newly-built facilities, defined in an indicative way depending on local conditions. It will enable creating "clean environment" urban and rural enclaves.

- Permitting the location of single wind installations along motorways (in the vicinity of the A4 and A1) and in the vicinity of some plants or in industrial districts - due to the lower landscape nuisance as well as access to energy infrastructure. Power plants should not be located in protected or recreation-leisure areas or in close vicinity of housing estates.

Actions address towards the environment should be also reflected in the pro-ecological and energy policy of particular regions, including the following:

- state entrepreneurship support in rural areas through an extended system of guarantees and sureties when it comes to using RES and increasing the effectiveness of using "clean" energy;

- conducting an extended educational-promotional-information campaign concerning the scope of using RES, supported by demonstration and pilot programmes as well as a campaign to spread the results of these programmes.

\section{Conclusion}

The idea of balanced development as well as development of modern technologies is the basis for the restructuring and revival of Silesian space.

Pic. 11. Prospective spatial structure of the Upper Silesian metropolis

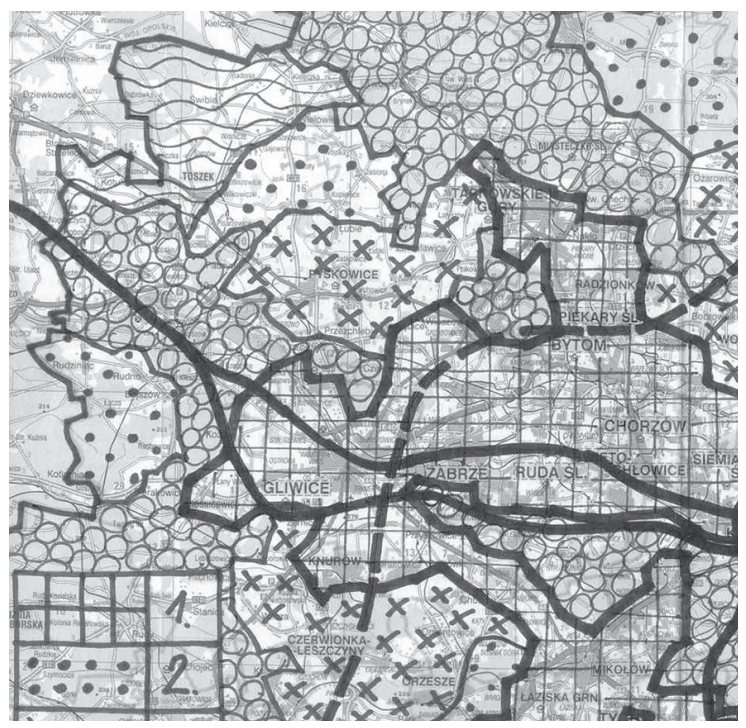

1 - urbanized areas of Upper Silesian metropolis

2 - areas of generating energy from renewable sources

3 - peripheral areas with RES agriculture;

4 - areas of forest with recreation function;

5 - ecological agriculture areas

Source: author's own work 


\section{NEW SPATIAL CONDITIONINGS OF REGIONAL DEVELOPMENT \\ Szymon Opania}

In this context, the development of renewable energy sources influences the future shape of the Upper Silesian metropolis through allowing for the crystallization of the area's spatial structure as well as counteracting suburbanization, protecting agricultural areas and areas of natural interest. The region's potential can be properly exploited, leading to constant, dynamic development in the future, through prospective spatial planning, aimed at improving the quality of post-industrial areas, along with the use of modern technologies and external funds.

\section{Bibliography:}

Bujakowski W., 2005, Program wykorzystania odnawialnych źródet energii na terenach nieprzemystowych województwa ślaskiego, Polish Academy of Sciences, Provincial Fund for Environment and Water Management Protection in Katowice, Katowice.

Gasidło K., Popczyk J., Kossak-Jagodzińska A., Kucharczyk P., Mazur K., Opania Sz., Pancewicz A., Schmiegel Z., 2007, Obszary metropolitalne i wielkie miasta a problem rozwoju i wykorzystania odnawialnych źródet energii (OZE) - rekomendacje dla Koncepcji Przestrzennego Zagospodarowania Kraju - Silesian University of Technology, Faculty of Architecture, Department of Urban and Spatial Planning, Gliwice.

Upper Silesian Metropolitan Union - geographical outline, [ed.] Dulias R., Hibszer A., Polish Geographical Society, Departament Katowice, Sosnowiec 2008.

Kubicka A., Opania Sz., 2009, Wyznaczenie najkorzystniejszych, alternatywnych sposobów pozyskiwania energii o zmniejszonej emisji $\mathrm{CO}_{2}$, dla województwa śląskiego oraz wyznaczenie ich lokalizacji, Department of Urban and Spatial Planning, Gliwice.

Ochrona Środowiska - informacje i opracowanie statystyczne, (2006), Central Statistical Office, Warsaw.

Opania Sz., 2007, Krajobraz kulturowy aglomeracji górnoślaskiej - próba definicji i waloryzacji, [w:] Krajobraz kulturowy - cechy, walory, ochrona, Maria Curie-Skłodowska University, Lublin. 
Opania Sz., 2000, Założenia restrukturyzacji krajobrazu obrzeży aglomeracji górnośląskiej, [w:] Restrukturyzacja i projektowanie systemów terytorialno-krajobrazowaych, Polish Association of Landscape Ecology, Słupsk.

Plan Zagospodarowania Przestrzennego Województwa Ślaskiego 2020+, 2016, Marshal of the Province of Silesia, Katowice.

Popczyk J., Kocot H., Korab R., Schmiegel Z. J., Kucharczyk P., Przekwas M., 2007, Analiza polskiego potencjatu rozwojowego w obszarze energetyki odnawialnej, z punktu widzenia możliwości wypetnienia przez Polskę celów unijnego pakietu energetycznego 3x20, Gliwice.

Strategia rozwoju Województwa Ślaskiego na lata 2005-2020, 2005, Local Government of the Province of Silesia, Katowice.

Węcławowicz G., 2007, Analiza i identyfikacja międzyregionalnych uwarunkowań rozwoju w planowaniu strategicznym regionów - ekspertyza, Departament of Regional Policy, Ministry of Economy and Industry, Warsaw. 


\section{6 | NEW SPATIAL CONDITIONINGS OF REGIONAL DEVELOPMENT \\ Szymon Opania}

\section{Nowe uwarunkowania rozwoju regionalnego}

\section{STRESZCZENIE}

Artykuł dotyczy możliwości wykorzystania narzędzi z dziedziny planowania przestrzennego, nakierowanych na poprawę jakości przestrzeni terenów poprzemysłowych wraz z możliwościami wykorzystania nowoczesnych technologii z zakresu odnawialnych źródeł energii.

Analiza przeprowadzona była na przykładzie metropolii górnośląskiej, która charakteryzuje się wyraźnie wyodrębnionymi z przestrzeni województwa terenami przemysłowymi i poprzemysłowymi. Choć zajmują one jedynie ok. $8 \%$ powierzchni województwa, to stanowią o wizerunku regionu kojarzonego z zanieczyszczeniem i zdegradowanym środowiskiem. Stanowi to wyzwanie dla planistów i urbanistów.

Bezpośrednie otoczenie centralnej części województwa, tzw. GZM, dawniej Górnośląskiego Związku Metropolitalnego, a od kwietnia 2017 Górnośląsko-Zagłębiowskiej Metropolii, tworzy szczególne warunki do pozyskiwania i stosowania odnawialnych źródeł energii. Jest to podstawą do realizacji idei zrównoważonego rozwoju wraz z rozwojem nowoczesnych technologii, ale przede wszystkim restrukturyzacji i odnowy śląskiej przestrzeni. Ponadto rozwój odnawialnych źródeł energii wpłynąć może na krystalizację struktury przestrzennej i przeciwdziałanie suburbanizacji oraz ochronę terenów rolniczych i przyrodniczo cennych. W konsekwencji perspektywiczne planowanie przestrzenne, skierowane na poprawę jakości przestrzeni terenów poprzemysłowych wraz z możliwościami wykorzystania nowoczesnych technologii oraz funduszy zewnętrznych, może dać gwarancję właściwego wykorzystania potencjału regionu wraz z jego ciąłym, dynamicznym rozwojem w przyszłości oraz wpłynąć na zmianę jego negatywnego wizerunku.

Studium przypadku dotyczy aglomeracji górnośląskiej. Jednak przyjęte kierunki rozwoju, w tym m.in. zapobieganie suburbanizacji oraz wykorzystanie produkcji rolnej do pozyskiwania odnawialnych źródeł energii są na tyle uniwersalne, iż mogą być wykorzystane w każdym innym przypadku.

\section{dr hab. inż. arch. Szymon Opania}

Research interests: architecture, urban studies, spatial planning, urban economy, sustainable development, urban regeneration, environmental protection in spatial planning, quality assessment of spatial structures, development processes in the Upper Silesian agglomeration.e-mail: szymon.opania@polsl.pl

Katedra Urbanistyki i Planowania Przestrzennego, Wydział Architektury, Politechnika Śląska.

Obszar zainteresowań badawczych: architektura, urbanistyka, planowanie przestrzenne, gospodarka miejska, zrównoważony rozwój, rewitalizacja, ochrona środowiska w planowaniu przestrzennym, ocena jakości struktur przestrzennych, procesy rozwoju Aglomeracji Górnośląskiej. 